\title{
Hepatitis C Virus Genotypes in Serum and Liver of Children with Chronic Hepatitis C
}

\author{
INMACULADA CASTILLO, JAVIER BARTOLOMÉ, MERCEDES RUIZ-MORENO, \\ VICTOR SANCHEZ, SONIA NAVAS, AND VICENTE CARREÑO \\ Hepatology Unit [I.C., J.B., S.N., V.C.] and Department of Pediatrics [M.R.-M., V.S.], \\ Fundación Jiménez Díaz, and Fundación para el Estudio de las Hepatitis Virales [I.C., J.B., S.N., V.C.], \\ Madrid, Spain
} \begin{abstract}
ABS
Hepatitis $\mathrm{C}$ virus (HCV) 1a, $1 \mathrm{~b}, 2 \mathrm{a}$, and $2 \mathrm{~b}$ subtypes have
been studied in 30 serum samples and in 20 paired liver biopsies from children with chronic hepatitis $\mathrm{C}$. One serum sample was negative to the four HCV subtypes studied. HCV $1 \mathrm{~b}$ was detected alone in $53.3 \%(16 / 30)$ of the serum samples; HCV 1a alone in $23.3 \%(7 / 30)$ and a mixed infection in $20 \%(6 / 30)$. In liver samples, HCV mixed infection was detected in a significantly higher proportion $(50 \%: p<0.05)$ than in serum, whereas $\mathrm{HCV}$ $1 \mathrm{~b}$ was detected alone in $35 \%(7 / 20)$ and HCV 1a alone in the remaining $15 \%(3 / 20)$ of liver samples. These results suggest that serum HCV genotyping may not reflect the viral population
\end{abstract}

Since identification of the $\mathrm{HCV}$ as the major causative agent of postransfusional non-A, non-B hepatitis (1), different HCV types and subtypes have been described (2). The development of PCR-based methods for HCV genotyping (3-5) has permitted the study of the prevalence of HCV types and subtypes in adult patients with chronic hepatitis $\mathrm{C}(3,6)$. Most of these studies have shown that HCV type 1 is prevalent in European countries (7-9). The pathobiology of the different HCV types is, furthermore, currently under active investigation (10-12). However, all these studies have been based on the analysis of $\mathrm{HCV}$ types in serum, and, to our knowledge, there have been no reports concerning detection of $\mathrm{HCV}$ types in liver cells.

In this study, we have determined the prevalence of $\mathrm{HCV}$ types 1 and 2 in serum and in liver samples from Spanish children with chronic hepatitis $\mathrm{C}$.

\section{METHODS}

All 30 children included in this study (mean age: $10.1 \pm 4.5$ $y$; range 2-17) had increased ALT levels for at least 6 mo previous to study entry; all had a chronic hepatitis histologically proven (24 chronic persistent hepatitis, 6 chronic active hepatitis), and all had serum HCV-RNA. Of these 30 children,

Received for rapid publication March 5, 1995; accepted July 11, 1995.

Correspondence: Dr. Vicente Carreño, Hepatology Unit, Fundación Jiménez Díaz, Avda. Reyes Católicos, 2, 28040 Madrid, Spain.

Supported by Fundación para el Estudio de las Hepatitis Virales, Madrid, Spain. infecting the liver of a given patient. Additional studies should be performed concerning the pathobiology of hepatitis $\mathrm{C}$ virus with relation to the subtypes detected in liver. (Pediatr Res 38: 618-620, 1995)
$\mathrm{HCV}$, hepatitis $\mathrm{C}$ virus
Abbreviations
PCR, polymerase chain reaction
ALT, alanine aminotransferase
RFLP, restriction fragment length polymorphism

$24(80 \%)$ were anti-HCV positive. The suspected acquisition route of $\mathrm{HCV}$ infection was postransfusional in 21 cases $(70 \%)$, parenteral injection in $4(13 \%)$, and unknown in the remaining $5(17 \%)$. Paired serum and frozen liver samples were available from 20 children. Written consent to perform the liver biopsies was obtained from the children's parents.

Anti-HCV was detected by ELISA II (Ortho Diagnostic System, Raritan, NJ) and confirmed by RIBA II (Ortho). Detection of serum HCV-RNA was carried out by nested PCR, using primers from the $5^{\prime}$-noncoding region, as previously described (13). Total RNA from liver biopsies was obtained by using the RNAgents kit (Promega Corp., Madison, WI), following supplier instructions, and the amount of isolated total RNA was measured by spectrophotometry at $260 \mathrm{~nm}$. HCV 1a, $1 \mathrm{~b}, 2 \mathrm{a}$, and $2 \mathrm{~b}$ subtypes were detected in serum and in $1 \mu \mathrm{g}$ of total liver RNA, following the method described by Okamoto et al. (3). The amplified products were visualized in an $8 \%$ polyacrylamide gel stained with ethidium bromide. Selected PCR products were directly cloned, using the TA Cloning kit (Invitrogen Corp., Sand Diego, CA), and clones were isolated and sequenced by the dideoxynucleotide chain termination reaction (Sequenase kit, U.S. Biochemical Corp., Cleveland, $\mathrm{OH})$. Moreover, in an attempt to investigate the presence of HCV types $3,4,5$, and 6 , serum samples were also typed by RFLP analysis of the DNA amplified from the 5 -noncoding region of the $\mathrm{HCV}$ genome (5). 
Fisher's test and $t$ test for $n<30$ were used for statistical comparisons.

\section{RESULTS}

The RFLP analysis of serum samples showed that 29/30 children had HCV type 1, whereas the remaining child presented RFLP patterns that might be compatible with $\mathrm{HCV}$ types 1 and 2 . In no case HCV types 3, 4, 5, and 6 were detected. By typing with primers derived from the core region, $\mathrm{HCV} 1 \mathrm{~b}$ was the subtype most frequently detected in serum samples $(16 / 30 ; 53.3 \%)$. HCV 1a was found in seven children $(23.3 \%)$, whereas another six patients $(20 \%)$ presented a mixed HCV infection: five cases with HCV $1 a+1 b$ and one with HCV $1 b+2 a$ (this latter child was also the one who presented RFLP patterns compatible with HCV types 1 and 2). HCV $2 b$ was not detected, either alone, or in combination with another HCV genotype. Only one child proved negative for these four tested HCV subtypes, although he had HCV type 1 by RFLP analysis.

Mixed HCV infection was detected in the liver samples available from 20 patients, with significantly $(p<0.05)$ greater frequency than in serum $(10 / 20,50 \%$ versus $6 / 30,20 \%$, respectively). Thus, nine liver biopsies had $\mathrm{HCV} 1 \mathrm{a}+1 \mathrm{~b}$, and one had HCV $1 \mathrm{~b}+2 \mathrm{a}$. HCV $1 \mathrm{~b}$ alone was detected in seven $(35 \%)$ liver samples, whereas the other three $(15 \%)$ liver biopsies had HCV 1a alone. The specificity of mixed $\mathrm{HCV}$ infections ( $\mathrm{HCV} \mathrm{1a}+1 \mathrm{~b})$ was proven by the sequencing of PCR products obtained from the liver biopsies of the children (Fig. 1).

The comparison of results obtained in serum with those obtained in liver samples is shown in Table 1. All HCV mixed infections detected in serum were confirmed in the liver. In contrast, several HCV infections detected in serum with one
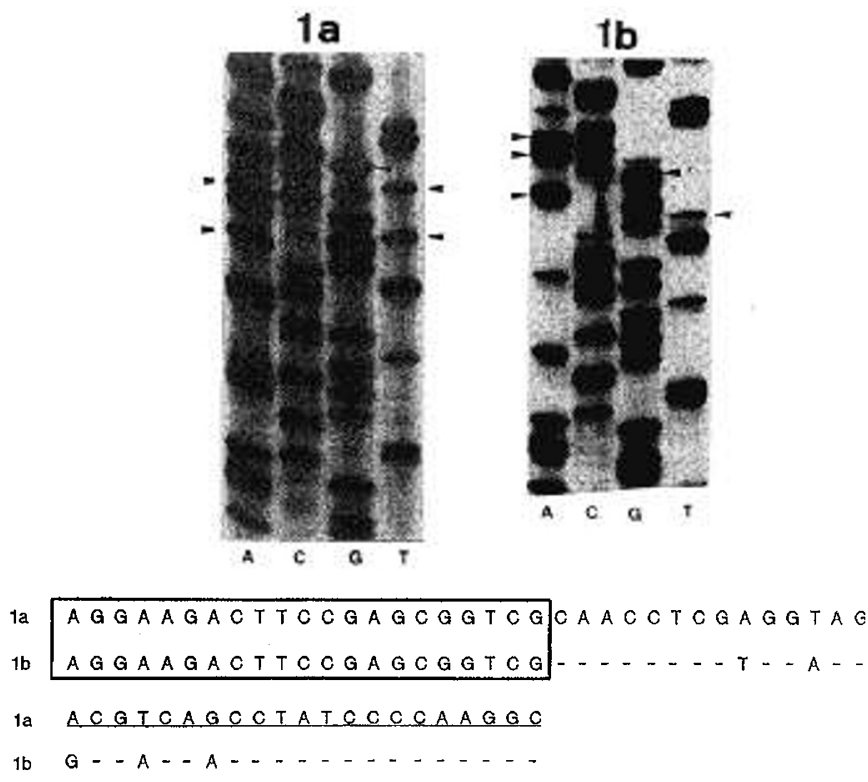

Figure 1. Sequences of cloned HCV $1 \mathrm{a}$ and $1 \mathrm{~b}$ amplified products obtained from the liver of a child simultaneously infected by both subtypes. The universal sense primer, as described by Okamoto et al. (3), is boxed. The HCV 1a antisense primer is underlined. Specific nucleotide changes for HCV 1a and $1 \mathrm{~b}$ subtypes are shown in the autoradiograms by arrowheads.
Table 1. Comparison of HCV subtypes detected in paired serum and liver samples

\begin{tabular}{cll}
\hline & \multicolumn{2}{c}{ HCV subtypes } \\
\cline { 2 - 3 } Patient no. & Serum & Liver \\
\hline 1 & $1 \mathrm{~b}$ & $1 \mathrm{a}+1 \mathrm{~b}$ \\
2 & $1 \mathrm{a}$ & $1 \mathrm{a}+1 \mathrm{~b}$ \\
3 & $1 \mathrm{~b}+2 \mathrm{a}$ & $1 \mathrm{~b}+2 \mathrm{a}$ \\
4 & $1 \mathrm{~b}$ & $1 \mathrm{a}+1 \mathrm{~b}$ \\
5 & $1 \mathrm{a}+1 \mathrm{~b}$ & $1 \mathrm{a}+1 \mathrm{~b}$ \\
6 & $1 \mathrm{~b}$ & $1 \mathrm{~b}$ \\
7 & $1 \mathrm{~b}$ & $1 \mathrm{~b}$ \\
8 & $1 \mathrm{a}$ & $1 \mathrm{a}$ \\
9 & $1 \mathrm{~b}$ & $1 \mathrm{~b}$ \\
10 & $1 \mathrm{~b}$ & $1 \mathrm{~b}$ \\
11 & $1 \mathrm{a}$ & $1 \mathrm{a}$ \\
14 & $1 \mathrm{a}$ & $1 \mathrm{a}$ \\
15 & $1 \mathrm{a}+1 \mathrm{~b}$ & $1 \mathrm{a}+1 \mathrm{~b}$ \\
16 & $1 \mathrm{a}+1 \mathrm{~b}$ & $1 \mathrm{a}+1 \mathrm{~b}$ \\
18 & Negative & $1 \mathrm{~b}$ \\
19 & $1 \mathrm{~b}$ & $1 \mathrm{a}+1 \mathrm{~b}$ \\
20 & $1 \mathrm{~b}$ & $1 \mathrm{~b}$ \\
21 & $1 \mathrm{~b}$ & $1 \mathrm{~b}$ \\
22 & $1 \mathrm{a}$ & $1 \mathrm{a}+1 \mathrm{~b}$ \\
25 & $1 \mathrm{a}$ & $1 \mathrm{a}+1 \mathrm{~b}$ \\
\hline
\end{tabular}

subtype alone were manifested as mixed HCV infection in liver samples ( $3 / 6$ serum HCV 1 a and $3 / 9$ serum HCV 1 b). Finally, the child who resulted negative in serum for the four HCV subtypes studied (with primers from the core region) had HCV $1 \mathrm{~b}$ in his liver sample.

No statistical differences were found between serum HCV subtypes and ALT levels, although children with HCV $1 \mathrm{~b}$ had higher ALT values $(115 \pm 100 \mathrm{IU} / \mathrm{L})$ than those with $\mathrm{HCV} 1 \mathrm{a}$ $(68 \pm 48 \mathrm{IU} / \mathrm{L})$ or those with a mixed infection (79 \pm 33 ). When ALT levels were compared with relation to HCV subtypes detected in liver samples, similar values were found between children with only one HCV subtype and those with mixed infection $(105 \pm 61$ versus $104 \pm 121 \mathrm{IU} / \mathrm{L}$, respectively). In addition, there was no relation between serum or liver HCV subtypes and the histologic diagnosis (data not shown).

\section{DISCUSSION}

This study is the first to report the prevalence of HCV 1a, $1 \mathrm{~b}$, $2 \mathrm{a}$, and $2 \mathrm{~b}$ subtypes in serum from children with chronic hepatitis $\mathrm{C}$, in comparison with paired liver samples.

HCV $1 \mathrm{~b}$ was the subtype most frequently detected in serum from children, but a high proportion of mixed $\mathrm{HCV}$ infection has also been found. These results are in agreement with those which we previously reported in adult patients with chronic hepatitis $C(9)$. The reason for the relatively high number of mixed HCV infection is unknown and requires further investigation.

When HCV typing was performed in the paired liver samples available, the presence of mixed HCV infection was not only confirmed but was, as well, significantly increased with respect to the percentage found in serum. In this context, six children with only one HCV subtype in serum had a double $\mathrm{HCV}$ infection in their liver cells. There are two possible 
explanations for this discrepancy: first, the HCV-RNA load may be higher in liver cells than in serum, permitting detection of the HCV subtype present at lower concentration in the hepatocytes; second, HCV genotyping in serum may reflect only those HCV types which are actively replicating in hepatocytes and are secreted to circulation, whereas, in liver cells, those other HCV types might also be detected in an inactive replication phase, or latent infection. Nevertheless, these hypotheses should be proven in future studies by the quantification of HCV-RNA, in both serum and liver samples, as well as by the detection in liver of the specific HCV-RNA negative strand of each subtype.

On the other hand, no significant relations were found among HCV subtypes (detected in serum and in liver) and ALT levels, or histologic diagnosis. This may be due to the relatively small number of children included in this study; therefore, further studies should be performed, increasing the number of serum and liver samples.

In summary, this study demonstrates that different results can be obtained on performing HCV typing in serum and in liver samples. Additional studies should be carried out concerning the pathobiology of HCV with relation to HCV subtypes detected in liver, as, to our knowledge, all published information relating to this matter has been exclusively based on serum HCV genotyping.

\section{REFERENCES}

1. Kuo G, Choo Q-L, Alter HJ, Gitnik GL, Redeker AG, Purcell RH, Miyamura T, Diengstag JL, Alter MJ, Stevens CE, Tegtemjer GE, Bonino F, Colombo M, Lee
W-S, Kuo K, Berger K, Shuster JR, Overby LR, Bradley DW, Houghton M 1989 An assay for circulating antibodies to a major etiologic virus of human non-A, non-B hepatitis. Science 244:362-364

2. Bukh J, Purcell RH, Miller RH 1994 Sequence analysis of the core gene of 14 hepatitis C virus genotypes. Proc Natl Acad Sci USA 91:8239-8243

3. Okamoto H, Sugiyama Y, Okada S, Kurai K, Akahane Y, Sugai Y, Tanaka T, Sato K, Tsuda F, Miyakawa Y, Mayumi M 1992 Typing hepatitis C virus by polymerase chain reaction with type-specific primers: application to clinical surveys and tracing infectious sources. J Gen Virol 73:673-679

4. Stuyver L, Rossau R, Wyseur A, Duhamel M, Vanderborght R, Van Heuverswyn $H$, Maertens G 1993 Typing of hepatitis C virus isolates and characterisation of new subtypes using a line probe assay. J Gen Virol 74:1093-1102

5. McOmish F, Yap PL, Dow BC, Follett AC, Seed C, Keller AJ, Cobain TJ, Krusius T, Kolho E, Naukkarinen R, Lin C, Lai C, Leong S, Medgyesi GA, Hejjas M, Kiyokawa H, Fukada K, Cuypers T, Saeed AA, Al-Rasheed AM, Lin M, Simmonds P 1994 Geographical distribution of hepatitis C virus genotypes in blood donors: an international collaborative survey. J Clin Microbiol 32:884-892

6. Dusheiko G, Schmilovitz-Weiss H, Brown D, McOmish F, Yap P-L, Sherlock S, McIntyre N, Simmonds P 1994 Hepatitis C virus genotypes: an investigation of type-specific differences in geographic origin and disease. Hepatology 19:13-18

7. Müller HM, Pfaff E, Goeser T, Theilmann L 1993 Genetic variability of German hepatitis $C$ virus isolates. J Med Virol 40:291-306

8. Pistello M, Maggi F, Vatteroni L, Cecconi L, Panicucci F, Bresci GP, Gambardella L, Taddei M, Bionda A, Tuoni M, Bendinelli M 1994 Prevalence of hepatitis C virus genotypes in Italy. J Clin Microbiol 32:232-234

9. Pernas M, Bartolomé J, Castillo I, Quiroga JA, Pardo M, Carreño V 1995 Sequence of non structural regions 3 and 5 of hepatitis $C$ virus genome from Spanish patients: existence of a predominant variant related to type 1b. J Gen Virol 76:415-20

10. Takada N, Takase S, Enomoto N, Takada A, Date T 1992 Clinical backgrounds of the patients having different types of hepatitis $C$ virus genomes. J Hepatol 14:35-40

11. Yoshioka K, Kakumu S, Wakita T, Ishikawa T, Itoh Y, Takayanagi M, Higashi Y, Shibata M, Morishima T 1992 Detection of hepatitis C virus by polymerase chain reaction and response to interferon- $\alpha$ therapy: relationship to genotypes of hepatitis $\mathrm{C}$ virus. Hepatology 16:293-299

12. Pozzato G, Kaneko S, Moretti M, Crocé LS, Franzin F, Unoura M, Bercich L, Tiribelli C, Crovatto M, Santini G, Kobayashi K 1994 Different genotypes of hepatitis $\mathrm{C}$ virus are associated with different severity of chronic liver disease. J Med Virol 43:291-296

13. Castillo I, Bartolomé J, Navas S, Gonzalez S, Herrero M, Carreño V 1994 Virological and biochemical long-term follow-up of patients with chronic hepatitis $\mathrm{C}$ treated with interferon. Hepatology 19:1342-1346 